Universidad de Lima

Facultad de Derecho

Carrera de Derecho

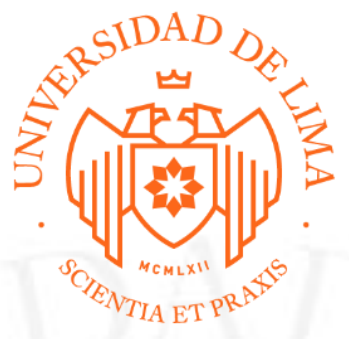

\title{
CIVIL: "INDEMNIZACIÓN POR DAÑOS Y PERJUICIOS" Y MINERO: "DERECHO MINERO AMBIENTAL"
}

Trabajo de suficiencia profesional para optar el Título Profesional de Abogada

\author{
Avalos Vega, Verónica Thaís
}

Código 20120128

Lima - Perú

Junio de 2019 


\section{CIVIL: "INDEMNIZACIÓN POR DAÑOS Y PERJUICIOS"}

Materia: Indemnización por daños y perjuicios

$\mathrm{N}^{\mathrm{o}}$ de Expediente: 08034-2006-0-1801-JR-CI-25

\section{RESUMEN}

El expediente trata de una demanda de indemnización por daños y perjuicios interpuesta por el señor A. A. A. A., en el que como petitorio solicita que los demandados le paguen solidariamente la suma de treinta $\$ 30,000.00$ por conceptos de daño personal, moral, psicológico, económico, emergente y lucro cesante, producto del accidente de tránsito ocurrido el 4 de mayo de 2004.

MINERO: "DERECHO MINERO AMBIENTAL"

Materia: Derecho minero ambiental

$\mathrm{N}^{\mathrm{o}}$ de Expediente: 0259-09-MA/E

RESUMEN

El expediente abarca los procedimientos administrativos sancionadores iniciados por el Organismo de Evaluación y Fiscalización Ambiental - OEFA a las empresas B. B. B. S.A., C. C. C. S.A.C, D. D. D. D. S.A., E. E. E. S.A. y F. F. S.A.C.; producto de las infracciones ambientales detectadas en la supervisión realizada por el Organismo Supervisor de la Inversión en Energía y Minería- OSINERGMIN que tuvo por finalidad verificar el cumplimiento de los compromisos de responsabilidad individual derivados de sus actividades mineras; así como los compromisos de responsabilidad compartida respecto a las acciones de remediación contempladas en el "Plan de Cierre Integral de Pasivos Ambientales Mineros del Río San Juan y Delta Upamayo", aprobado mediante Resolución Directoral No 001-2009MEM/AAM del 6 de enero de 2009. 